\title{
The Importance of Social Competences Transformation towards Early Age Children in Jakarta
}

\author{
Tjipto Sumadi*, Asep Rudi Casmana \\ Department of Pancasila and Citizenship Education, Faculty of Social Science, Universitas Negeri Jakarta, Indonesia
}

Received February 22, 2020; Revised April 7, 2020; Accepted April 19, 2020

Copyright $(2020$ by authors, all rights reserved. Authors agree that this article remains permanently open access under the terms of the Creative Commons Attribution License 4.0 International License

\begin{abstract}
The purpose of this research is how to transform social values competencies to efforts at the kindergarten of PatraIII Jakarta. Based on several premilinary studies, the social competences are considered to be very imperative, especially for the students in the kindergarten. As such, the purpose of this research is how the process of social values transformation has been implemented by teachers to their pupils. To undertake this study, a qualitative approach is used to identify the participants. Descriptive method is used to write and see more detail about how the schools transform social competences. The informants were principals and teachers of kindergarten. The results of the research are as follows: (1) There were twenty-eight media used by the teachers who have done the transformation of social values to their pupils. The process of transformation included of social values competencies dimensions i.e.; social values competencies, emotional, and pupils' maturity attitude. (2) The efforts of transformation as a strategic to internalizing and customizing pupils. (3) The process of transformation could be guided to pupils as an early charity for 4-5 years old in social competencies values, emotional, and maturity. As such, it can be concluded that social competences are considered to be important, so that the school should transform these skills. This study can contribute towards a new knowledge for the researcher in education, especially for those who are interested in the pupils studying in Kindergarten.
\end{abstract}

Keywords Social Values Competencies, Social Values Competencies Transformation, Early Childhood

\section{Introduction}

Transformation of competence of social values is an event that often occurs in communities and school institutions, as well as in kindergartens. Every generation always wishes that the values it believes will be continued by the next generation, as well as what happens in TK Prata III Jakarta.

The learning process or transformation of the values of social competence at Patra III Kindergarten Jakarta (2007) has a curriculum and learning program that aims to (1) introduce regulations and instill discipline in children, (2) introduce children to the world around them, (3) foster good attitudes and behavior, (4) develop communication and socializing abilities, (5) develop children's skills, creativity, and abilities, and (6) prepare children to enter primary education.

Also, the scope of the TK Patra III curriculum (2007) also includes aspects of development, (1) moral and religious values, (2) social, emotional, and independence, (3) language skills, (4) cognitive, (5) physical / motor, and (6) art

The development of social competency values refers to the process of developing competencies needed as a provision in formally relating as expected by the surrounding community (Saracho and Spodeck, 2007). It was even stated also that to develop the values of social competence of children, it is necessary to identify what values must be transformed into children, so that children can face challenges they face. Saracho and Spodeck (2007) states more fully: "Identifying these components and processes can lead to interventions for parents (at home) and teachers (at school) who do not spontaneously provide effective parenting and where they have children at risk for less optimal development "

On the other hand, Bruner in Saracho and Spodek (2007) states that each child tends to have three developmental phases, namely (1) enactive mode; individual use actions to stand for information (i.e. trying a shoe), (2) iconic mode; individual use visual images to interpret information (i.e. thinking some one's face), (3) symbolic mode; individual use language.

Vygotsky in Santrock (2002) gives a categorization of children's cognitive development as a zone of proximally 
development or ZPD. Vygotsky explained that early children tend to have difficulty coping with problems faced by themselves. However, if the child gets a little help or guidance from the adults around him or the teacher at school, then the child will be better able to overcome the problems they face. Vygotsky strongly believes in the importance of social influences in the developmental period of cognition and the role of the learning process or the transformation of values in the child's development.

According to Hurlock (2007), children aged 4-6 years have been able to express rejection in the form of physical reactions and verbal forms. At this time, children begin to use lies to defend themselves, complain, pretend not to hear, and the like. This tendency is a form of negativism as a result of certain social situations. On the other hand, children can also begin to work together. The more children get along with other children, the faster the children can work together. In the process of working together, the child will give or convey the values obtained from his home, and vice versa, the child will simultaneously receive the values that exist in the family of his playmates. In this interaction, there will be an exchange of values between them. If the process of exchanging values is relatively the same, there will be harmony between them. Conversely, if during the process of working together between them, there are striking differences in values, then it can be possible that there will be a mismatch, even the possibility of a fight can occur.

Research examining children's competencies among others was conducted by Heejeong Sophia Han and Kristen Mary Kemple (2004), who stated that the decision to encourage the development of children's competencies must be based on the knowledge and main competencies developed. An effective strategy is needed to encourage the emergence of all competencies possessed by children. This research is a development of component models of social competencies that have been carried out previously, which illustrate that the same strategies may not be used to transform the competencies of social values based on different cultures.

The results of research by Vlasta Gmitrova and Juraj Gmitrov (2003) stated that children between 3 - 6 years old showed children's affection and cognition according to the taxonomy put forward by Bloom and Krathwohl. This study also revealed a significant increase in the manifestations of children's cognition during the process of playing in groups. This research also proves that there is a significant relationship between children's social competence and their cognitive level, the higher the age of the child, the higher the social competence.

Research conducted by Burton L. White (1979) states that students' assignments in schools regarding social competence are categorized into two types, namely social tasks and nonsocial tasks. Tasks that have social competency values are:

"To please, to cooperate, to gain approval, to procure a service, to gain attention or to achieve social contact, to maintain social contact, to avoid unpleasant circumstances, to reject overtures and peer contact, to avoid attention, to annoy, to dominate, to compete, to resist domination, to enjoy pets, to provide information, to converse, and to produce of verbalizations ".

Meanwhile, tasks that show individual skills or competencies but not as social competencies are:

"To eat, to relieve, to dress oneself, to ease discomfort, to restore order, to choose, to procure an object, to construct a product, to engage in large-muscle activity, to avoid behavior, to pass time, to find something, to prepare for an activity, to explore, to pretend - to rule play, to improve a developing motor - intellectual or verbal skills, to gain information (visual), to gain information (auditory and visual), to gain pleasure, to imitate, and to operate a mechanism ".

This study aims to describe the process of transformation of the values of social competence of students aged 4 to 5 years in Patra III Kindergarten Jati Pulogadung, East Jakarta. While specifically this study also aims to find a comprehensive and in-depth overview of the process of transforming social competency values carried out by teachers to students, knowing the overall and in-depth picture of teachers' understanding of the transformation of social competency values to students in kindergarten Patra III Jati Pulogadung Jakarta.

\section{Research Method}

This research uses descriptive method with ethnographic approach. Through this research method, direct and in-depth observations are conducted at the location of the research site, as well as taking serious notes.

The data obtained in this study relates to (1) the dimensions of social competency values that are transformed by principals and teachers to students, (2) reasons principals and / or teachers transform social competency values to students, and (3) ways of transforming social competency values carried out by principals and teachers to students.

Data collection procedures are carried out through three stages, namely; (1) descriptive observation; conduct a comprehensive orientation or exploration of the location under study, (2) focused observation or exploration; efforts to dig up information on the focus under study, and (3) selected observations; characteristic grouping of research results.

The analysis conducted in this study refers to the naturalistic research model proposed by Spradley, namely by conducting data analysis together with when the research takes place in the field. Data analysis and data collection were carried out simultaneously with four stages, namely (1) domain analysis, (2) taxonomic analysis, (3) 
componential analysis, and (4) theme analysis.

\section{Results}

The results showed that there were 28 social competency values, 9 emotional competency values, and 5 independence competency values transformed in Patra III Kindergarten Jakarta. All of these values fall into three dimensional categories. These three dimensions of competency values are empirically conducted by principals and teachers to students through the process of playing and learning. The first dimension is the values of social competence based on ethics, norms, and adaptation or adaptation of children to the values that develop in society. The values of social competence consist of 28 types, namely, praying before and after carrying out activities, imitating the implementation of worship activities in a simple, do not disturb those who are doing religious activities, ask for help well, say hello, always be friendly, thankful if get something, implement orderly in school, follow the rules of the game, want to budge, listen to parents or friends talk, speak politely in speaking, not be irritable or shouting, easy to get along or friends, can or like to help friends, help each other friends, showing pride in their own work, using other people's belongings carefully, lending their property with pleasure, cleaning themselves with a little help, taking care of themselves with a little help, returning to its place after use, taking out the trash in its place, helping clean up the environment, patiently waiting for gil iran, stop playing on time, willing to accept assignments, recognize and avoid dangerous objects, know one's own belongings and those of others.

The second dimension is values that are emotionally related. These emotional-based values consist of nine types, namely, singing simple religious songs, mentioning places of worship, mentioning religious holidays, mentioning times of worship, mentioning God's creations, willing to divide their possessions, willing to separate with mother without crying, persuaded, and not whiny.

The third dimension is the values related to independence. These values based on independence consist of four types, namely being able to do their own tasks, doing their tasks to completion, getting to know and avoiding dangerous drugs, and carrying out assignments given by the teacher.

The main reason for TK Patra III Jakarta to transform the values of social competence to children is to develop moral potential, social-emotional skills, cognitive development, and language skills, both Indonesian and English. Besides that, it also develops and creates creative and independent children. The transformation of the values of social competence developed by TK Patra III Jakarta is based on the theory that the child is a person who is very good at imitating but not a good listener. Thus the principal and / or teacher believes that through efforts to transform the values of social competence to students, it is a strategic program to develop the potential possessed by students.

The method used by school principals and teachers in transforming social competency values consisting of three dimensions (social competence, emotional competence, and independence competency) is to carry out a process of transformation together. Examples of the way teachers make polite language transformation in speaking.

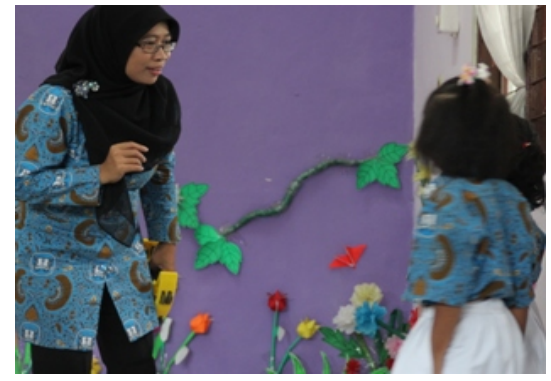

Figure 1. The teacher invites children to get used to speaking politely

Based on the figure 1, it can be seen how the teacher communicate to the students using the polite language. This polite speaking can transform the character because students can follow them. The values of social competence are transformed to children in this dimension so that children express their ideas politely. Speaking politely does not mean ignoring the substance of the ideas conveyed. The transformation process of talking to others is exemplified in Figure 1 above. Emotionally body language can also be used to support politeness when speaking.

\section{Discussions}

Empirically the transformation of the values of social competence from school principals and / or teachers to students in TK Patra III Jakarta has been carried out in three dimensions categories, namely dimensions of social competency values, dimensions of emotional competency values, and dimensions of values independence competency. These three transformed competencies refer to standards of learning in kindergartens so that children have experience playing, learning, and socializing while at school.

Standards of learning competence in kindergartens include, (1) having confidence, being aware of and exercising rights and obligations, respecting each other and giving a sense of security, in accordance with their religion, based on the religion of their parents, (2) using language to understand, develop and communicate ideas and information, and to interact with others, (3) choose, integrate, and apply concepts and techniques, patterns, structures, and relationships, (4) choose, seek, and apply technology and information needed from various sources, (5) understanding and valuing the physical world, living things, and technology and using knowledge, skills and values to make the right decisions, (6) participate, interact, 
and play an active role in society and culture global based on understanding cultural, geographical and historical contexts, (7) creating and appreciating artistic, cultural and intellectual works and $\mathrm{m}$ apply noble values to increase personal maturity towards civilized society, (8) think logically, critically, and laterally by calculating the potential and opportunities to deal with various possibilities, and (9) show motivation in learning, confident, working independently and working same with other people.

Based on these competency standards, grades, content, messages transformed in Patra III Kindergarten are the achievement of optimal children's development tasks according to the standard. These aspects of development are achieved through the transformation of aspects of the values of social competence, emotional competence, and independence competence, which are enriched with values based on moral, religious, linguistic, cognitive, cognitive, physical / motoric, and artistic. Through the transformation of the values of competence, stimulation, stimulation, guidance, and habituation, children can improve the development of their behavior and attitudes, so that this becomes the basis in shaping the child's personality in accordance with the values in society.

The values of social competence based on religion in Patra III Kindergarten are praying before and after carrying out activities, imitating the implementation of worship activities in a simple manner, and not disturbing those who are conducting worship activities. All of these value bases were well transformed by Patra III Kindergarten teachers.

The values of social competence that are transformed based on manners include, asking for help well, saying hello, always being friendly, grateful if you get something, the implementation needs to be improved. Remembering when students do the values of this manners, often teachers do not give praise to students. Basically praise from the teacher is a motivation for children to be willing to carry out these values to become a habit.

The values of social competence are transformed based on implementing order and following the rules of the game implemented according to the provisions. In this section, children are asked to follow order in school. Teachers should give examples by doing not just giving verbal messages to students.

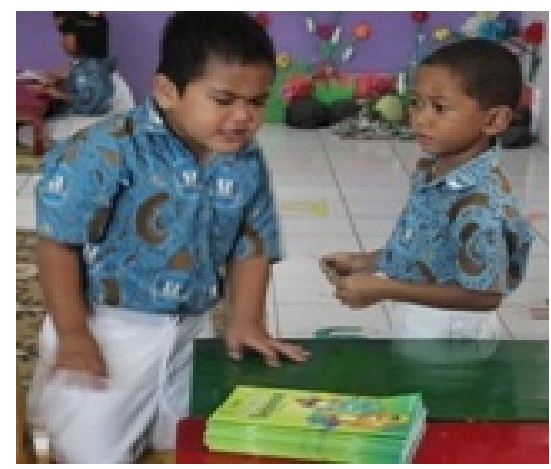

Figure 2. The child expressing anger
Based on the figure 2, it can be seen that anger is considered to be the verbal expression. This expression can show how the transformation of social competence among the students.

The values of social competence are transformed based on being willing to budge, listening to parents or friends' talk, speaking politely in speaking, not being irritable or shouting, easy to get along with or friends, can or like to help friends, and helping each other friends are values delivered by the teacher to the child. In fact, there are still children who are screaming and angry.

The values of social competence are transformed on the basis of showing pride in the results of one's own work, using other people's belongings carefully and lending their property are happily found at TK Patra III. All students tend to dare to show proudly their work, use school items carefully, and tend to lend their property.



Figure 3. Students show the results of their work

Figure 3 revealed the cooperation between students, and it can improve the social competences because they work together.

Transformed social competency values are based on cleaning oneself with a little help and taking care of themselves with a little help occur in Patra III. When children go to the toilet to defecate, simultaneously several children follow it. This phenomenon shows that the values of social competence can become habits in life.

The values of social competence are transformed based on returning goods to their place after use, throwing trash in their place, and helping to clean the environment have been done by the teacher to students. Children always throw garbage in its place, return orderly items that have been used, and always keep the environment clean.

The values of social competence are transformed on the basis of patiently waiting for their turn, stopping to play on time, willing to accept the task already carried out. In this section, children are accustomed to follow the existing provisions. Through this habituation, children are expected to become good members of the community.

The values of social competence that are transformed based on knowing and avoiding dangerous objects, knowing one's own belongings, and those of others are carried out by the teacher, but not explicitly. Explanation to 
students only about not being allowed to take medicine without parental supervision. The contents, messages and transformation values in this section are drugs that are not taken as prescribed can be dangerous.

The emotional competence values that are transformed based on singing simple religious songs, mentioning places of worship, mentioning religious holidays, mentioning times of worship, and mentioning God's creations, have been transformed by the teacher. All students are encouraged to get used to carrying out religious commands in accordance with the beliefs held by their parents.

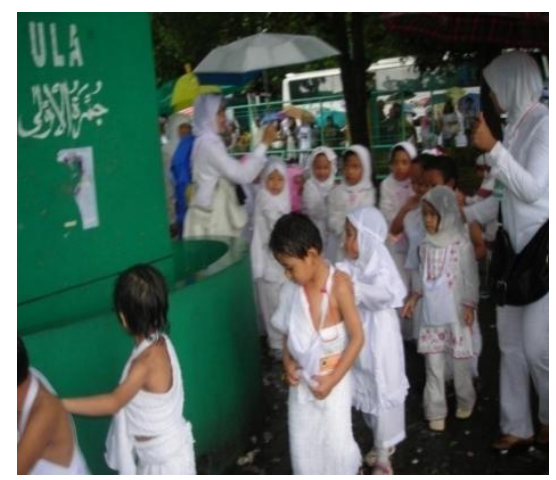

Figure 4. Habitual worship according to the religion that is believed

In the figure 4 , it is revealed that the religious activities can transform the social values. They enjoy to help one another during worship.

The values of competencies that are transformed based on willingness to share their possessions have been conveyed by the teacher. Children are accustomed to valuing food brought by themselves and their friends. Transforming emotional competency values is intended so that children can make the habit of giving to others with pleasure.

The values of emotional competence that are transformed to children based on wanting to separate from the mother without crying, can be persuaded, and not whiny, have been carried out by the teacher. In carrying out the planting of emotional competency values, the teacher is assisted by the pre-school to welcome children who are escorted by their parents. The meeting between parents and kindergarten organizers is important, because this is meaningful as the delivery of guidance and development of children's potential to schools (TK).

The values of independence competence are transformed based on children who are able to do their own tasks, do the assignments to completion, and are willing to carry out the tasks given by the teacher. The transformation of the values of independence of competence conveyed by the teacher aims to build the child's awareness that each child receives a task that must be carried out with full responsibility. Children can not live alone forever, children certainly need the help of others, both peers, and people who are more mature. Because children cannot live alone, children need to be accustomed to being willing to accept assignments according to their responsibilities.
The implementation of early childhood education can never be carried out with just one approach. Therefore, to implement the findings of this dissertation, a comprehensive transdisciplinary approach is needed. The development of social competency values in children aged 4-6 years, in the context of the values of social competence, emotional, and independence is the next potential development of the first 1000 days of life (HKP) of children. In order for children to grow and develop in accordance with the values of wisdom around them, a holistic and transdisciplinary approach is needed by (1) creating a program to build collective awareness between parents and schools (TK) about the importance of nutrition for children's growth, especially at $1000 \mathrm{HKP},(2)$ creating a habituation program for children to implement the values of social competence, emotional, and independence through daily activities, and (3) organizing joint activities between PAUD experts in universities, schools (kindergarten), and parents.

\section{Conclusions}

Based on research findings at TKPatra III Jakarta, there are three dimensions of social competency values, namely; the values of social competence that are the focus of research, and the two dimensions of the research subfocus namely; dimensions of emotional competency values and dimensions of independence competency values. The three competency values are closely related to each other. In full, the conclusions of this study are;

1. There are 28 (twenty-eight) values of social competence that are the focus of research. The values of social competence are transformed by the teacher to students through habituation. The focused values are; pray, imitate worship, do not interfere with worship activities, ask for help, say hello, be friendly, give thanks, carry out discipline, follow the rules, be willing to budge, listen to parents, speak politely, not be irritable, easy to be friends, helpful, help each other, take pride in one's own work, be careful, lend with pleasure, clean yourself, take care of yourself, return goods in their place, throw trash in their place, help clean the environment, be patient, be on time, be willing to accept assignments, avoid dangerous objects, and distinguish ownership of goods. There are also 9 (nine) dimensions of emotional competency values consisting of; sing songs, times of worship, places of worship, and religious holidays, mention the creation of God, willing to share, willing to separate, willing to be persuaded, and not whiny. The next dimensions of competency values are 4 (four) values of independence competence consisting of; can do their own tasks, work on assignments to completion, avoid dangerous drugs, and are willing to carry out tasks from the teacher. 
2. TK Patra III implements the values of social competence with the aim of providing habituation for children, motivating, and providing examples through behavior. Transforming values of social competence is a strategic effort to instill and accustom children to behaving in accordance with the values of social competence in society. Transformation of social competency values is given as an initial provision for early childhood (ages 4-5 years), especially with regard to the values of social competence, emotional, and independence.

3. The process of transforming social competency values is not done through a verbal approach but with guidance and invites children to familiarize themselves in implementing the values of transformed social competence. Transformation of values of social competence which is done through example (imitation) can be more accepted by children than delivery which is definitive, because children are not good listeners, but children are great imitators.

\section{Acknowledgements}

We are very grateful to experts for their appropriate and constructive suggestions to improve this template.

\section{REFERENCES}

[1] Han, Heejeong Sophia dan Kristen Mary Kemple, (2006) Components of Social Competence and Strategies of Support: Considering What to Teach and How, Earlly Childhood Education Journal Vol. 34, No.3 Desember 2006, New York.

[2] Hurlock, Elizabeth B. (2007), Perkembangan Anak, (Alih Bahasa Meitasari Tjandrasa dan Muslichah Zarkasih, Jakarta: Erlangga.

[3] Santrock, Jhon W., (2002). Life-Spain Development, Perkembangan Masa Hidup, edisi 5, Jakarta: Penerbit Erlangga.

[4] Saracho, Olivia N., dan Bernard Spodek ed. (2007), Contemporary Perspective on Socialization and Social Development in Early Childhood Education, New York: Information Age Pub. Inc.

[5] Seefeldt, Carol dan Nita Barbour, (1994), Early Childhood Education: An Introduction, New York: MacMillan College Pub. Company.

[6] Smith, Jeffrey Trawick (2003)Early Childhood Development: A Multicultural Prespective, Ohio: Merrill Prectice Hall.

[7] Soemiarti Patmonodewa, (2003). Pendidikan Anak Prasekolah, Jakarta: Aneka Cipta.

[8] Spradley, James P. (1997). Metode Etnografi. Yogyakarta: PT Tiara Wacana.
[9] Vlasta Gmitrova dan Juraj Gmitrov, (2003) The Impact of Teacher-Directed and Child-Directed Pretend Play on Cognitive Competence in Kindergarten Children, Earlly Childhood Education Journal Vol. 34, No.3 Desember 2003(New York).

[10] White, Burton L., Barbara T. Kaban, dan Jane S. Attanucci, (1979). The Origins of Human Competence, Printed in the United States of America 